\title{
DETECÇÃO DE DNA DE Neospora caninum NO FÍGADO DE FILHOTE DE CADELA SOROPOSITIVA PARA $N$. caninum - RELATO DE CASO
}

(Detection of Neospora caninum DNA in a liver sample of the puppy from a litter of seropositive bitch - Case report)

Flávia Moreira da Fonseca, Ana Paula Sato, Guillherme Francisco da Cruz Filho, Rosangela Locatelli Dittrich

Universidade Federal do Paraná, Curitiba, Paraná, Brasil.

*Correspondência: flaviamoreiravet@gmail.com

RESUMO: O Neospora caninum é um protozoário intracelular identificado pela primeira vez como causador de encefalomielite e miosite em cães e desde então foi detectado em ampla variedade de animais domésticos. O cão e os canídeos selvagens são os hospedeiros definitivos do protozoário e eliminam oocistos nas fezes e se infectam pela ingestão de cistos em tecidos infectados. Embora a transmissão vertical seja altamente eficiente em vacas, a transmissão congênita de Neospora caninum por infecção natural em cães é pouco relatada (DUBEY \& SCHARES, 2011). O objetivo do presente estudo foi relatar a presença de DNA de Neospora caninum em amostra de fígado de um filhote de uma ninhada de uma cadela soropositiva. Uma cadela da raça Bulldog Francês de 3 anos de idade, matriz reprodutora de um criatório de cães e assintomática, apresentava histórico de uma primeira gestação de 3 de 5 filhotes que desenvolveram sinais neurológicos e vieram a óbito nas primeiras semanas de vida. Essa cadela apresentou soropositividade para Neospora caninum na RIFI com titulação 1:100. Amostras de tecidos desses filhotes necropsiados foram testados para $N$. caninum no PCR e foram negativos. Ela foi inseminada artificialmente novamente com sêmen de um macho soronegativo para uma segunda gestação. Nessa gestação nasceram cinco filhotes, sendo que quatro apresentaram sinais clínicos, como letargia, dispnéia, dificuldade para mamar, choro persistente, ataxia e opacidade da córnea, que se iniciaram aos cinco aos setes dias de vida. Foram tratados com clindamicina e sulfa com trimetropim, mas vieram a óbito no décimo dia. Os filhotes foram necropsiados e amostras de tecidos (Cérebro, coração, fígado, rim, pulmão e timo) foram coletadas para a realização do diagnóstico molecular e análise histopatológicade. A extração de DNA foi realizada com kit comercial. Para a amplificação de DNA $N$. caninum foi empregada a reação de cadeia da polimerase nested-PCR com os primers NP6 plus, NP21 plus, NP7 e NP6, que amplificam a região NC5. Foi detectado DNA de $N$. caninum na amostra do fígado. $\mathrm{Na}$ análise histopatológica os tecidos não apresentaram alterações macroscópicas e microscópicas sugestivas de neosporose. A transmissão transplacentária em cadelas não é eficiente, cerca de $80 \%$ dos filhotes de cadelas soropositivas não são infectados, mas cadelas com infecção subclínica pode transmitir o protozoário em gestações sucessivas (BARBER \& TREES., 1998). A maioria dos relatos são de infecções experimentais, nem sempre é observada a transmissão vertical e a ocorrência pode variar entre as gestações. Os casos de neosporose mais graves geralmente acometem filhotes infectados congenitamente e os sinais clínicos se iniciam a partir das três semanas após o nascimento. $O$ presente relato ressalta a possibilidade de transmissão congênita de $N$. caninum em cadelas em gestações sucessivas, a importância de realizar sorologia para $N$. caninum nas matrizes reprodutoras dos criatórios e retirá-las da reprodução em caso de soropositividade.

Palavras-chave: apicomplexa; cão; PCR; transmissão congênita

\section{Referências}

DUBEY, J. P.; SCHARES, G. Neosporosis in animals-the last five years. Veterinary parasitology, v. 180, n. 1-2, p. 90-108, 2011.

BARBER, J. S.; TREES, A. J. Naturally occurring vertical transmission of Neospora caninum in dogs. International journal for Parasitology, v. 28, n. 1, p. 57-64, 1998. 